\title{
Phenolic Profiles and Biological Activities of Extracts from Edible Wild Fruits Ehretia tinifolia and Sideroxylon lanuginosum
}

\author{
Imelda N. Monroy-García ${ }^{1}$, Irma Edith Carranza-Torres ${ }^{1,2}$, Pilar Carranza-Rosales ${ }^{2}$ (D) María Oyón-Ardoiz ${ }^{3}$, \\ Ignacio García-Estévez $^{3}$ D , Jesús Fernando Ayala-Zavala ${ }^{4}$, Javier Morán-Martínez ${ }^{5}$ (D) and \\ Ezequiel Viveros-Valdez ${ }^{1, *(D)}$
}

Citation: Monroy-García, I.N.;

Carranza-Torres, I.E.;

Carranza-Rosales, P.; Oyón-Ardoiz,

M.; García-Estévez, I.; Ayala-Zavala,

J.F.; Morán-Martínez, J.;

Viveros-Valdez, E. Phenolic Profiles and Biological Activities of Extracts from Edible Wild Fruits Ehretia tinifolia and Sideroxylon lanuginosum. Foods 2021, 10, 2710. https://doi.org/ $10.3390 /$ foods 10112710

Academic Editor: Rubén Domínguez

Received: 14 October 2021

Accepted: 3 November 2021

Published: 5 November 2021

Publisher's Note: MDPI stays neutra with regard to jurisdictional claims in published maps and institutional affiliations.

Copyright: (c) 2021 by the authors Licensee MDPI, Basel, Switzerland. This article is an open access article distributed under the terms and conditions of the Creative Commons Attribution (CC BY) license (https:// creativecommons.org/licenses/by/ $4.0 /)$

1 Deparatmento de Química, Facultad de Ciencias Biológicas, Universidad Autónoma de Nuevo León, Av. Pedro de Alba S/N, San Nicolás de los Garza 66450, Nuevo León, Mexico; Imelda.monroygrc@uanl.edu.mx (I.N.M.-G.); irma.carranza@uanl.edu.mx (I.E.C.-T.)

2 Centro de Investigación Biomédica del Noreste, Instituto Mexicano del Seguro Social, Jesús Dionisio González \#501, Col. Independencia, Monterrey 64720, Nuevo León, Mexico; carranza60@yahoo.com.mx

3 Grupo de Investigación en Polifenoles, Departamento de Química Analítica, Nutrición y Bromatología, Facultad de Farmacia, Campus Miguel de Unamuno, Universidad de Salamanca, E37007 Salamanca, Spain; m.oyon@usal.es (M.O.-A.); igarest@usal.es (I.G.-E.)

4 Coordinación de Tecnología de Alimentos de Origen Vegetal, Centro de Investigación en Alimentación y Desarrollo A.C., Carretera Gustavo Enrique Astiazarán Rosas No. 46, Hermosillo 83304, Sonora, Mexico; jayala@ciad.mx

5 Facultad de Medicina, Universidad Autónoma de Coahuila Unidad Torreón, Gregorio A. García No. 198, Torreón 27000, Coahuila, Mexico; javiermoranmartinez@uadec.edu.mx

* Correspondence: jose.viverosvld@uanl.edu.mx

\begin{abstract}
Ehretia tinifolia Linnaeus (Boraginacea) and Sideroxylon lanuginosum Michaux (Sapotaceae) are wild fruits consumed in North America and are appreciated for their pleasant flavor and sweet taste. However, details regarding their composition and biological properties in the available literature are scarce. This study reports the phenolic composition, antioxidant, antiproliferative activities, and digestive enzymatic inhibition of amberlite-retained methanolic extracts from both fruits. Results revealed that these wild fruit extracts are rich in antioxidants. S. lanuginosum had lower phenolic but higher flavonoid contents $(21.4 \pm 1.5 \mathrm{mg} \mathrm{GAE} / 100 \mathrm{~g} \mathrm{FW}$ and $6.42 \pm 0.9 \mathrm{mg}$ $\mathrm{CE} / 100 \mathrm{~g} \mathrm{FW})$ than E. tinifolia $(64.7 \pm 2.6 \mathrm{mg} \mathrm{GAE} / 100 \mathrm{~g} \mathrm{FW}$ and $5.1 \pm 0.4 \mathrm{mg} \mathrm{CE} / 100 \mathrm{~g}$ FW) HPLC-DAD-MS/MS analysis showed rosmarinic acid as a major polyphenol in E. tinifolia and quercetin glucoside in S. lanuginosum. Polyphenols content in E. tinifolia was related to a significant free radical scavenging ability: $\mathrm{DPPH}\left(\mathrm{EC}_{50}=0.32 \pm 0.03 \mathrm{mg} / \mathrm{mL}\right), \mathrm{TEAC}(4134 \pm 9.7 \mu \mathrm{M} \mathrm{TE} / \mathrm{g}$ dry extract), and hemolysis inhibition $\left(\mathrm{IC}_{50}=58.55 \pm 2.4 \mu \mathrm{g} / \mathrm{mL}\right)$. Both extracts were capable of inhibiting $\alpha$-glucosidase, partially inhibiting $\alpha$-amylase, and showed no inhibition against lipase, while showing antiproliferative activity against HeLa, HT-29 and MCF-7 cancer cell lines. Our study revealed that these wild fruit extracts are rich in health-beneficial phytochemicals and hold significant potential for elaborating functional foods.
\end{abstract}

Keywords: wild fruits; antioxidant; phenolic compounds; HPLC-DAD-MS/MS

\section{Introduction}

In recent years, exploratory studies have been developed to identify endemic wild fruits as promising crops with high economic value [1]. Likewise, producing scientific evidence of the properties of these wild resources is highly relevant to evaluating their contribution to local biodiversity and assessing their effects on nutrition and human health $[2,3]$. Ehretia tinifolia Linnaeus (Boraginacea), commonly called pinguica and Sideroxylon lanuginosum Michaux (Sapotaceae), known as Gum Bully, Black Haw, or Coma, are 
wild fruits appreciated for their pleasant flavor and sweet taste and have been consumed in North America by Native Americans since pre-Columbian times. Thus, wild plants have an important role in indigenous peoples' lives [4] as they supplement staple foods to provide a balanced diet to many populations in several regions across Mexico, mainly in the states of Michoacán, Nayarit, Nuevo León, San Luis Potosí, Sinaloa, Tamaulipas, and Veracruz. It has also been used in the southeastern USA, mostly used by the Kiowa and Comanche tribes [5]. E. tinifolia are small globoid yellow drupes of up to $8 \mathrm{~mm}$ diameter, with a sweet flavor and have been used as food and medicinal plant in several regions of Mexico and the USA [6-9]. Bromatological analysis of E. tinifolia has already been reported, and the content of total phenols in polar organic extracts (50 to $125 \mathrm{mg}$ per 100 $\mathrm{g}$ of fresh fruit) is related to its antioxidant properties [10]. S. lanuginosum is also used in the north of Mexico and by native tribes of the USA as chewing gum [11]. However, there are no reports of the chemical composition or biological activity of this fruit. Therefore, expanding the chemical/biological knowledge of these species would add value to the possible production and commercialization of nutraceuticals or functional foods.

It is well known that fruits have antioxidants with a beneficial impact on human health Phenolic compounds, ascorbate and carotenoids are the main antioxidants found in fruits [12]. The main phenolic components present in fruits are glycosylated flavones/flavonols, flavanones, anthocyanins, and phenolic acids [13]. Epidemiological studies and randomized clinical trials showed a strong association between polyphenol consumption and reduced risk of several chronic diseases, including cancer, diabetes, and inflammatory processes [14]. Dietary plant polyphenols modulated metabolism of carbohydrates and lipids, controlled hyperglycemia, dyslipidemia and insulin resistance, increased metabolism in adipose tissues, and alleviated oxidative stress and stress-sensitive signaling pathways and inflammatory processes in several in vitro, animal models and some human studies [12]. Furthermore, cancer prevention is one of the most documented biological properties of polyphenols. In cancer, these compounds induced apoptosis, reduced the number of tumors, inhibited angiogenesis, modulated multidrug resistance and antiproliferative activity [15]. Polyphenols also modulated the expression of cytochrome P-450 enzymes and activation of carcinogens [16].

Wild fruits with antioxidant activity have also become the object of an increasing number patent claims on behalf of the food and beverage industry. Wild rose fruit and jujube mixtures have been used to claim the formulation of an antioxidant beverage [17]. In addition, wild pawpaw has been used to formulate cakes [18]. At the same time, wild indigo fruit and wild blueberries have been used to formulate beers claiming to enhance vision and human immunity [19]. Wild rose fruit rich in polyphenols has been used to formulate cosmetics with skin repair activity [20]. Similarly, wild cherries were used to formulate beverages claiming to be useful on dietary therapies [21]. Additionally, Berbenol ${ }^{\circledR}$ (PharmExtrcta, Pontenure, Italy), a tablet formulation made from an extract of Berberis aristata D.C. and Silybum marianum (L.) Gaertn fruit is used to treat glycemia and lipid value alterations in patients with type 2 diabetes [22]. These patents evidence the potential economic impact of knowing the bioactive composition of wild fruits.

In this context, this study aimed to identify the phenolic profiles and contents from $E$. tinifolia and S. Lanoginosum from the north of Mexico and to evaluate the antiradical, antidiabetic and anticarcinogenic properties. This information would highlight their potential use in elaborating functional foods and preserving and revalorizing their use as traditional foods.

\section{Materials and Methods}

\subsection{Plant Material}

Ripe and healthy pinguicula and coma fruits were collected by hand from wild trees located in San Nicolas de los Garza, N.L. (northeast Mexico; Latitude: $25^{\circ} 44^{\prime} 31.9^{\prime \prime} \mathrm{N}$; Longitude: $100^{\circ} 16^{\prime} 59.3^{\prime \prime} \mathrm{W}$ ) and Higueras, N.L. (northeast Mexico; Latitude: $25^{\circ} 57^{\prime} 59.3^{\prime \prime} \mathrm{N}$; Longitude: $100^{\circ} 00^{\prime} 52.5^{\prime \prime} \mathrm{W}$ ), respectively, from May to August 2019. Fruits were immedi- 
ately transported to the laboratory for processing. The authenticity of the collected species was confirmed by Dr. Marco Guzmán Lucio, taxonomist and responsible for the herbarium of the Faculty of Biological Sciences of the Autonomous University of Nuevo Leon.

\subsection{Phytochemicals Extraction}

The method used for phytochemicals extraction was reported previously by ViverosValdez, et al. [23]. E. tinifolia and S. lanuginosum fresh fruits were washed with distilled water, and seeds were removed manually. One hundred grams of each fruit pulp and peel were squeezed and mixed with $1 \mathrm{~L}$ of distilled water using a commercial blender. The mixtures were filtered using Whatman No.1 filter paper, and each juice was applied onto an Amberlite XAD-7 column $(150 \times 10 \mathrm{~cm})$, which had been conditioned previously with $2 \mathrm{~L}$ of distilled water. The XAD-7 column was washed with distilled water (3 L) to eliminate proteins, carbohydrates, minerals and organic acids, while the retained phenolic compounds were eluted with methanol $(\mathrm{MeOH})(2 \mathrm{~L})$. Subsequently, the solvent was evaporated until dryness under reduced pressure and lyophilized for analysis. Yellow and purple extracts were obtained from E. tinifolia (w/w yield: $0.87 \%$ ) and S. lanuginosum (w/w yield: $0.51 \%$ ), respectively. Lyophilized extracts were stored at $4{ }^{\circ} \mathrm{C}$ for a maximum period of 6 months.

\subsection{Determination of Total Phenolic Content (TPC)}

Total phenolic content was determined using the Folin-Ciocalteu reagent as described by Singleton and Rossi [24] with some modifications. Total phenolic content includes free and bound phenolics. The freeze-dried extracts were dissolved in distilled water to a concentration of $0.1 \mathrm{mg} / \mathrm{mL}$. Then, $30 \mu \mathrm{L}$ of each fruit extract, $150 \mu \mathrm{L}$ of Folin-Ciocalteu reagent (1:10 v/v in distilled water) and $120 \mu \mathrm{L}$ of an aqueous solution of $\mathrm{Na}_{2} \mathrm{CO}_{3}(7.5 \%$ $w / v)$ were placed into a 96-well plate and incubated for $30 \mathrm{~min}$ at room temperature in darkness. Absorbance was measured at $765 \mathrm{~nm}$ (Agilent BioTek Epoch Microplate Spectrophotometer), using gallic acid solutions as standards (concentrations range of $10-1000 \mu \mathrm{g} / \mathrm{mL}$ in distilled water $)\left(y=0.0681 \mathrm{x}+0.0732 ; \mathrm{R}^{2}=0.9848\right)$, and results were expressed as milligrams of gallic acid equivalents (GAE) per $100 \mathrm{~g}$ of fresh weight (FW). Data were reported as mean \pm S.D. for at least three replications.

\subsection{Determination of Total Flavonoid Content (TFC)}

Total flavonoid content was determined using the aluminum chloride colorimetric assay [25]. Fruit extracts were diluted with $\mathrm{MeOH}(1 \mathrm{mg} / \mathrm{mL})$. Then, $250 \mu \mathrm{L}$ of fruit extract or standard solution of (+) Catechin (concentration range of $50-500 \mu \mathrm{g} / \mathrm{mL}$ of MeOH) was mixed with $1000 \mu \mathrm{L}$ of distilled water and $75 \mu \mathrm{L}$ of $\mathrm{NaNO}_{2}$ solution $(7 \% w / v$ in distilled water). After $5 \mathrm{~min}$ at room temperature, $75 \mu \mathrm{L}$ of $\mathrm{AlCl}_{3}$ aqueous solution $(10 \% w / v)$ were added. One minute later, $500 \mu \mathrm{L}$ of $1 \mathrm{M} \mathrm{NaOH}$ and $600 \mu \mathrm{L}$ of distilled water were added and vigorously mixed. The absorbance in the reaction mixture was measured at $496 \mathrm{~nm}$ (Agilent BioTek Epoch Microplate Spectrophotometer). The values of the calibration curve are $y=0.0124 x+0.0173 ; R^{2}=0.9995$. Results were expressed as $\mathrm{mg}(+)$ Catechin Eq. $/ 100 \mathrm{~g}$ of fresh weight $(\mathrm{FW})$. Data are reported as mean \pm S.D. for at least three replications.

\subsection{Antiradical and Antioxidant Assays}

\subsubsection{2,2'-Diphenyl-1-Picrylhydrazyl Radical (DPPH•) Assay}

The ability of the phytochemical extracts to scavenge the 2,2'-diphenyl-1-picrylhydrazyl radical $\left(\mathrm{DPPH}^{\bullet}\right)$ was assessed following the methodology proposed by Braca, et al. [26] with some modifications. Fruit extract $(1 \mathrm{mg} / \mathrm{mL}$ of $\mathrm{MeOH})$ was added to a $150 \mu \mathrm{M}$ methanol solution of $\mathrm{DPPH}^{\bullet}$ in a serial dilution 1:1 (v/v) ratio. Absorbance at $517 \mathrm{~nm}$ was determined after $30 \mathrm{~min}$ in darkness using a microplate spectrophotometer (Agilent BioTek Epoch) and converted into the percentage of antiradical activity (AA) using the following formula:

$$
\mathrm{AA} \%=100-[(\mathrm{As}-\mathrm{Ac}) \times 100 / \mathrm{Ac}]
$$


where Ac and As are the absorbance of the control and samples, respectively. $\mathrm{MeOH}$ was used as a negative control and Trolox as the positive control. Mean values were obtained from triplicate experiments. The radical scavenging activities were expressed as the median effective concentration $\left(\mathrm{EC}_{50}\right)(\mathrm{mg} / \mathrm{mL})$. The $\mathrm{EC}_{50}$ was calculated from the log-dose inhibition curve obtained by a nonlinear regression algorithm.

\subsubsection{Trolox Equivalent Antioxidant Capacity (TEAC) Assay}

The procedure followed the method of Gupta et al. [27] with slight modifications. An aqueous solution of the radical was prepared with $7 \mathrm{mM}$ ABTS and $2.45 \mathrm{mM}$ potassium persulfate dissolved in distilled water and kept for $16 \mathrm{~h}$ at room temperature in darkness. The solution was then diluted by mixing $\mathrm{ABTS}^{\bullet+}$ solution with deionized water to obtain an absorbance of $0.7 \pm 0.02$ units at $734 \mathrm{~nm}$ using a microplate reader (Agilent BioTek Epoch). In a 96-well microplate, $20 \mu \mathrm{L}$ of fruit extracts were allowed to react with $200 \mu \mathrm{L}$ of the $\mathrm{ABTS}^{\bullet+}$ solution for $20 \mathrm{~min}$ in darkness. Then the absorbance was measured at $734 \mathrm{~nm}$. The standard curve was linear between 25 and $600 \mathrm{mM}$ Trolox ( $\mathrm{y}=0.1095 \mathrm{x}-$ 9.8189; $R^{2}=0.9521$ ). Results are expressed in $\mu \mathrm{mol}$ of Trolox equivalents (TE)/g of dry extract.

\subsubsection{Protective Effect on Human Erythrocytes}

Hemolysis was induced by peroxyl radicals generated by AAPH (2-2'-Azobis (2amidinopropane dihydrochloride) according to the methodology of Silva-Beltrán et al. [28]. Then, $5 \mathrm{~mL}$ of blood was obtained from healthy human volunteers by venipuncture and collected into tubes containing EDTA as an anticoagulant. Erythrocytes were separated from plasma by centrifugation at $1500 \mathrm{rpm}$ for $10 \mathrm{~min}$ at room temperature and washed three times with five volumes of phosphate-buffered saline (PBS) $(37 \mathrm{mM}$ of NaCl, $2.7 \mathrm{mM}$ of $\mathrm{KCI}, 8 \mathrm{mM}$ of $\mathrm{Na}_{2} \mathrm{HPO}_{4}$, and $2 \mathrm{mM}$ of $\left.\mathrm{KH}_{2} \mathrm{PO}_{4} w / v\right)$ at $\mathrm{pH}$ 7.4. Later, erythrocytes were suspended in four volumes of PBS solution to obtain a density of $8 \times 10^{9}$ cells $/ \mathrm{mL}$.

The addition of AAPH to the suspension of washed erythrocytes induces oxidation of membrane lipids and proteins, resulting in hemolysis. The erythrocyte suspension $(250 \mu \mathrm{L})$ was mixed with $250 \mu \mathrm{L}$ of fruit extracts dissolved in PBS at concentrations of 500, 750, 1000, $2000 \mu \mathrm{g} / \mathrm{mL}$ and $250 \mu \mathrm{L}$ of $300 \mathrm{mM}$ AAPH in PBS. The reaction mixture was shaken gently while being incubated at $37^{\circ} \mathrm{C}$ for $3 \mathrm{~h}$. After the incubation, the reaction mixture was diluted with eight volumes of PBS and centrifuged at $4000 \mathrm{rpm}$ for $5 \mathrm{~min}$. The supernatant's absorbance was measured in a microplate reader (Agilent BioTek Epoch, Santa Clara, CA, United States) at $540 \mathrm{~nm}$. Percent inhibition was calculated by the following equation:

$$
\% \text { Inhibition }=\left[\mathrm{A}_{\mathrm{AAPH}}-\mathrm{As}\right] /\left[\mathrm{A}_{\mathrm{AAPH}} \times 100\right]
$$

where $\mathrm{A}_{\mathrm{AAPH}}$ is the absorbance of AAPH at $540 \mathrm{~nm}$ and As is the absorbance of the extracts at $540 \mathrm{~nm}$. The extract concentration providing $50 \%$ inhibition $\left(\mathrm{IC}_{50}\right)$ was also calculated from the dose-response curve obtained by plotting the percentage of hemolysis inhibition versus the extract concentration. Ascorbic acid was used as positive control and PBS as a negative control. Three independent experiments were used for these calculations.

\subsection{Digestive Enzymes Inhibition}

\subsubsection{Inhibition of $\alpha$-Glucosidase}

The $\alpha$-glucosidase inhibitory activity was evaluated according to the chromogenic method described by Kaskoos [29], with some modifications. Then, $50 \mu \mathrm{L}$ of serial dilutions of $5 \mathrm{mg} / \mathrm{mL}$ of fruit extract dissolved in PBS solution (pH 6.8, DMSO 1\%, v/v) was mixed with $50 \mu \mathrm{L}$ of $\alpha$-glucosidase (0.8 U/mL of PBS, pH 6.8). Then, the 96-well plate was incubated at $37^{\circ} \mathrm{C}$ for $15 \mathrm{~min}$. After that, $50 \mu \mathrm{L}$ of $625 \mathrm{mM} p$-nitrophenyl- $\alpha$-D-glucopyranoside (PNPG) solution was added to each well and incubated for another $15 \mathrm{~min}$. Subsequently, $100 \mu \mathrm{L}$ of $0.2 \mathrm{M} \mathrm{Na}_{2} \mathrm{CO}_{3}$ were added to stop the reaction and absorbance was measured at 
$405 \mathrm{~nm}$ using a UV-visible microplate reader (Agilent BioTek Epoch). The percent inhibition was calculated using the following formula:

$$
\% \text { Activity }=[\mathrm{Ac}-\mathrm{As} / \mathrm{Ac}] \times 100
$$

where Ac and As are the absorbance of control and sample, respectively, and acarbose was used as positive control and PBS solution as a negative control. The half-maximal inhibitory concentration $\left(\mathrm{IC}_{50}\right)$ was calculated using a logit analysis.

\subsubsection{Inhibition of $\alpha$-Amylase}

The $\alpha$-amylase inhibitory activity was evaluated according to Sudha et al. [30] with some modifications. $\alpha$-Amylase $(1 \mathrm{U} / \mathrm{mL}$ ) dissolved in PBS ( $\mathrm{pH}$ 6.8) was mixed with serial dilutions (with $5 \mathrm{mg} / \mathrm{mL}$ ) of fruit extract dissolved in PBS solution (pH 6.8, DMSO 1\%, v/v) in a 1:1 dilution $(v / v)$ and incubated in a 96 -well plate at $37^{\circ} \mathrm{C}$ for $15 \mathrm{~min}$. Then, $50 \mu \mathrm{L}$ of $0.5 \%$ starch solution in PBS was added to each well, and the reaction was incubated for $20 \mathrm{~min}$ at $37^{\circ} \mathrm{C}$. The reaction was stopped with $20 \mu \mathrm{L}$ of $1 \mathrm{M} \mathrm{HCl}$, followed by the addition of $50 \mu \mathrm{L}$ of iodine reagent ( $3 \mathrm{mM} \mathrm{I}_{2}$ and $\left.30 \mathrm{mM} \mathrm{KI}\right)$, and absorbance was measured at $750 \mathrm{~nm}$ using a UV-visible microplate reader (Agilent BioTek Epoch). The percent inhibition was calculated using the following formula:

$$
\% \text { Activity }=[\text { Ac }- \text { As } / \text { Ac }] \times 100
$$

where Ac and As are the absorbance of control and sample, respectively, and acarbose was used as a positive control and PBS solution as a negative control. The $\mathrm{IC}_{50}$ values were calculated using a logit analysis.

\subsubsection{Inhibition of Pancreatic Lipase}

The pancreatic lipase inhibitory activity was determined according to Maqsood et al. [31] with slight modifications, using $p$-nitrophenyl palmitate ( $p$-NPP) as a substrate. Under reaction conditions, the lipase enzyme hydrolyses $p$-NPP to release $p$-nitrophenol, a yellow-colored substance and can be measured at $410 \mathrm{~nm}$. Pancreatic lipase $(2.5 \mathrm{mg} / \mathrm{mL})$ was dissolved in phosphate buffer solution PBS $(60 \mathrm{mM}, \mathrm{pH} 8)$. In a 96-well microplate, $100 \mu \mathrm{L}$ of serial dilutions of fruit extract $(5 \mathrm{mg} / \mathrm{mL})$ or Orlistat was mixed with $30 \mu \mathrm{L}$ of lipase solution. It was incubated for $15 \mathrm{~min}$ at $37^{\circ} \mathrm{C}$. Then, $10 \mu \mathrm{L}$ substrate $p$-NPP $(10 \mathrm{mM}$ in DMSO) was added. After incubating the mixture for $30 \mathrm{~min}$ at $37^{\circ} \mathrm{C}$, its absorbance was measured at $405 \mathrm{~nm}$ in a microplate reader. The percent inhibition was calculated using the following formula:

$$
\% \text { Activity }=[\text { Ac }- \text { As } / \text { Ac }] \times 100
$$

where Ac and As are the absorbance of control and sample, respectively. The control contained all constituents except a test sample. Orlistat was used as a positive control. The $\mathrm{IC}_{50}$ values were calculated by logarithmic regression analysis.

\subsection{Antiproliferative Activity}

The antiproliferative effects of extracts of E. tinifolia and S. lanuginosum were assessed using the method described previously by Viveros-Valdez, et al. [32]. HeLa (ATCC ${ }^{\circledR}$ CCL-2), MCF-7 (ATCC ${ }^{\circledR}$ HTB-22) and HT-29 (ATCC ${ }^{\circledR}$ HTB-38) cancer cell lines were used. The cells were seeded in $25 \mathrm{~cm}^{2}$ tissue culture flasks in Dulbecco's modified eagle medium (DMEM) mixed with Ham's nutrients (Ham's F-12) and supplemented with 10\% fetal bovine serum (FBS), adjusting the $\mathrm{pH}$ to 7.2. A mixture of antibiotics composed of penicillin and streptomycin $(10,000 \mathrm{IU} / \mathrm{mL}: 10,000 \mu \mathrm{g} / \mathrm{mL} ; 1 \mathrm{~mL}$ of mixture $/ 1 \mathrm{~L}$ of medium) was added. Cells were maintained at $37{ }^{\circ} \mathrm{C}$ in an incubator under a $5 \% \mathrm{CO}_{2} / 95 \%$ air atmosphere at constant humidity. Cells were harvested by trypsinization, counted with a hemocytometer, and their viability was confirmed by Trypan Blue $(0.4 \%)$. The different cancer cell lines were seeded with 5000 cells per well in a 96 well plate. After incubation for $24 \mathrm{~h}, 100 \mu \mathrm{L}$ of fruit extracts (concentrations of 125, 500, 750, 1000, and 2000 
$\mu \mathrm{g} / \mathrm{mL}$ dissolved on PBS ( $\mathrm{pH}$ 7.2) were added and incubated for another $24 \mathrm{~h}$. $20 \mu \mathrm{L}$ of Alamar Blue Invitrogen ${ }^{\mathrm{TM}}$ (Waltham, MA, USA) solution $(10 \% v / v)$ was added to each well. The plate was incubated with agitation and the fluorescence was measured $4 \mathrm{~h}$ later in a fluorometer FLx800 Bio-Tek Instruments, INC (Waltham, MA, USA) (535 nm excitation and emission at $595 \mathrm{~nm}$ wavelength). Taxol was used as a positive control. The $\mathrm{IC}_{50}$ values were calculated by probit analysis.

\subsection{HPLC-DAD-ESI-MS/MS Analysis of Phenolics Profiles}

The phenolic composition was performed using a Hewlett-Packard 1100 Series liquid chromatograph (Agilent Technologies, Waldbronn, Germany) equipped with a Spherisorb S3 ODS-2 (80 ̊, $3 \mathrm{~mm}, 4.6 \mathrm{~mm} \times 150 \mathrm{~mm}) \mathrm{C}-18$ reversed-phase column (Waters Corporation, Milford, MA, USA) thermostatted at $35^{\circ} \mathrm{C}$. Optimization of the HPLC conditions was carried out for the analysis of these samples. The mobile phases employed were $0.1 \%(v / v)$ formic acid in water (solvent A) and 100\% HPLC-grade acetonitrile (solvent B). The elution was performed at a flow rate of $0.5 \mathrm{~mL} / \mathrm{min}$, and the gradient was established as follows: from $0 \%$ to $10 \%$ B for $3 \mathrm{~min}$, from $10 \%$ to $14.5 \%$ B for $34 \mathrm{~min}$, from $14.5 \%$ to $20 \%$ B for $3 \mathrm{~min}$, from $20 \%$ to $35 \%$ B for $15 \mathrm{~min}$ and from $35 \%$ to $60 \%$ B for $5 \mathrm{~min}$. The absorption spectra were recorded between 220 and $600 \mathrm{~nm}$, and detection was conducted at 250, 280, 330, and $370 \mathrm{~nm}$ as the preferred wavelengths. The HPLC system was coupled via the DAD outlet with a mass spectrometer API 3200 (AB Sciex LLC, Framingham, MA, USA) equipped with an electrospray ionization source and a triple quadrupole linear ion trap mass analyzer, controlled by the Analyst 5.1 software. Mass spectrometry detection was performed in negative mode as previously described by Cittadini et al. [33] for the analysis of flavanols and phenolic acids: declustering potential, $40 \mathrm{~V}$, entrance potential, and ion spray voltage were set at $40 \mathrm{~V}, 7 \mathrm{~V}$, and $5000 \mathrm{~V}$, respectively whereas GS1 GS2 and curtain gas were set at $40 \mathrm{psi}, 50 \mathrm{psi}$, and $20 \mathrm{psi}$, respectively, with collision gas as "high". A full mass analysis (collision energy $10 \mathrm{~V}$ ) and an $\mathrm{MS}^{2}$ analysis (collision energy $25 \mathrm{~V}$ ) were performed. The phenolic characterization was analyzed in $1 \mathrm{mg}$ of dry extract of each fruit resuspended in deionized water. Retention time, UV-vis spectra, parent ion, and fragmentation pattern data were used for compound identification. The differences in the relative abundance of the fragment ions obtained in MS/MS analysis of each compound were compared to the fragmentation patterns reported in the literature to differentiate between isomers.

\subsection{Statistical Analysis}

The values were expressed as mean $\pm \mathrm{SD}(n=3)$. The observed differences among means were performed using one-way analysis of variance (ANOVA), followed by Tukey's pairwise comparison of means. The statistical analysis was carried out by one way analysis of variance using SPSS (version 18) statistical analysis program. Statistical significance was considered at $p<0.05$.

\section{Results and Discussion}

3.1. Total Phenolic Content (TPC), Total Flavonoid Content (TFC), Antiradical, and Antioxidant Activity

The TPC was higher for E. tinifolia (64.7.4 $\pm 2.6 \mathrm{mg}$ GAE/100 g F.W.) compared with $S$. lanuginosum $(21.4 \pm 1.5 \mathrm{mg} \mathrm{GAE} / 100$ g F.W.) $(p<0.05)$ (Table 1). E. tinifolia extract showed higher TPC than ethanolic extracts of wild fruits Prunus spinosa, Rosa canina and Rubus sanctus $(0.29 \pm 0.02,0.23 \pm 0.02$ and $0.42 \pm 0.02 \mathrm{mg} \mathrm{GAE} / \mathrm{g}$ F.W., respectively) [34]. Otherwise, Pio-León et al. [10] evaluated the phenolics content of E. tinifolia fruits, and they found higher concentrations in the methanolic extract $(125.45 \pm 2.9 \mathrm{mg} / 100 \mathrm{~g}$ F.W. $)$ than in the ethanolic extract (50.25 $\pm 6.85 \mathrm{mg} / 100 \mathrm{~g}$ F.W.). Schmeda-Hirschmann et al. [35] determined the TPC for Sideroxylon obtusifolium, and it was lower ( $4.71 \pm 0.06 \mathrm{~g} \mathrm{GAE} / \mathrm{kg}$ F.W.) than $S$. lanuginosum in this study. The TPC on E. tinifolia is comparable with wild fruits as Eulychnia acida Phil. (80.6 $\pm 2.2 \mathrm{mg}$ GAE/100 g F.W.) [36], Garcinia atrovidiris (68.45 $\pm 0.9 \mathrm{mg}$ GAE/100g F.W.) and Durio zibenthinus (64.57 $\pm 3.43 \mathrm{mg} \mathrm{GAE} / 100$ g F.W.) [37]. 
Table 1. Total phenolic content, total flavonoid content, and antioxidant/antiradical capacities of Ehretia tinifolia and Sideroxylon laniginosum extracts.

\begin{tabular}{|c|c|c|c|c|c|}
\hline Sample & $\begin{array}{c}\text { TPC } \\
\text { mg GAE/100g F.W. }\end{array}$ & $\begin{array}{c}\text { TFC } \\
\text { mg CE/100g F.W. }\end{array}$ & $\begin{array}{c}\text { TEAC } \\
\mu \mathrm{mol} \mathrm{TE} / \mathrm{g}\end{array}$ & $\begin{array}{c}\text { DPPH } \\
\mathrm{EC}_{50} \mathrm{mg} / \mathrm{mL}\end{array}$ & $\begin{array}{l}\text { Hemolytic } \\
\text { Inhibition } \\
\mathrm{IC}_{50}(\mu \mathrm{g} / \mathrm{mL})\end{array}$ \\
\hline S. lanuginosum & $21.4 \pm 1.5^{b}$ & $6.42 \pm 0.9^{a}$ & $4134 \pm 97^{a}$ & $0.48 \pm 0.05^{\mathrm{a}}$ & $61.76 \pm 7.9^{b}$ \\
\hline E. tinifolia & $64.7 \pm 2.6^{a}$ & $5.1 \pm 0.4^{b}$ & $2454 \pm 38^{b}$ & $0.32 \pm 0.03^{b}$ & $58.55 \pm 6.5^{b}$ \\
\hline$* *$ Control & - & - & - & $0.013 \pm 2^{c}$ & $289 \pm 20^{a}$ \\
\hline
\end{tabular}

** Trolox was used on DPPH free radical scavenging assay and ascorbic acid on AAPH-induced hemolysis assay. $n=3,(a-c)$ on each column show significant differences among each determination, according to Tukey's test $(p<0.05)$.

TFC was higher for S. lanuginosum $(9.85 \pm 1.6 \mathrm{mg} \mathrm{CE} / 100 \mathrm{~g}$ F.W.) than E. tinifolia $(6.4 \pm 0.2 \mathrm{mg} \mathrm{CE} / 100 \mathrm{~g}$ F.W. $)(p<0.05)$ (Table 1). Both fruit extracts showed higher TFC than Litchi chinensis ( $6 \pm 1 \mathrm{mg}$ CE/100g F.W.) and Citrus reticulata $(4 \pm 1 \mathrm{mg}$ CE $/ 100 \mathrm{~g}$ F.W.) and Persea americana ( $2 \pm 1 \mathrm{mg} \mathrm{CE} / 100 \mathrm{~g}$ F.W. [38]. However, the flavonoid content of different solvents extractions of Ceratonia siliqua fruits fluctuated between 0 to $98.7 \pm$ $2.4 \mathrm{mg} \mathrm{CE} / 100 \mathrm{~g}$ F.W. These results suggest that the total flavonoid content was strongly affected by the extraction [39]. Therefore, the low flavonoid contents obtained may be due to the extraction method.

The present work evaluated the antiradical and antioxidant activity of the samples using three different assays, including in vitro $\mathrm{DPPH}^{\bullet}$ and TEAC assays and ex vivo inhibition of hemolysis in erythrocytes induced by AAPH. The antioxidant activity is summarized in Table 1. In all determinations, the most active extract was E. tinifolia. The antioxidant activity correlated with total phenolic compounds on this extract compared to $S$. lanuginosum. The $\mathrm{DPPH}^{\bullet}$ antiradical activities of E. tinifolia $\left(\mathrm{EC}_{50}=0.32 \pm 0.03 \mathrm{mg} / \mathrm{mL}\right)$ and S. lanuginosum $\left(\mathrm{EC}_{50}=0.48 \pm 0.05 \mathrm{mg} / \mathrm{mL}\right.$ ) were higher than reported for other wild fruits. Pulp and peel extracts from Cydonia oblonga fruit showed $\mathrm{DPPH}^{\bullet}$ free radical scavenging activities $\mathrm{EC}_{50}$ of 0.6 and $0.8 \mathrm{mg} / \mathrm{mL}$, respectively [40] and XAD7 extract from Prumnopitys andina reported an $\mathrm{EC}_{50}$ of $0.93 \pm 0.03 \mathrm{mg} / \mathrm{mL}$ [41]. For the TEAC assay, E. tinifolia showed a lower TEAC value $(2454 \mu \mathrm{M} / \mathrm{g})$ than S. lanuginosum $(4134 \mu \mathrm{M} / \mathrm{g})(p<0.05)$. Both fruits presented high antiradical activity regarding other wild fruits such as Prunus espinosa (5080

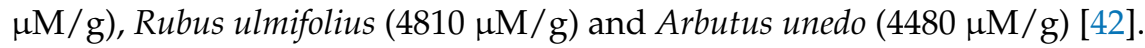

The measurement of oxidative hemolysis in erythrocyte membranes represents a good model to study antioxidant and pro-oxidant compounds. AAPH was used as a peroxylradical generator to induce hemolysis in human erythrocytes. The protective capacity of $E$. tinifolia and S. lanuginosum extracts on human red blood cells, using AAPH radical showed values of $\mathrm{IC}_{50}$ of $58.55 \mu \mathrm{g} / \mathrm{mL}$ and $61.76 \mu \mathrm{g} / \mathrm{mL}$, respectively (Table 1). Our results showed similar $\mathrm{IC}_{50}$ values compared to epicatechin ( $\mathrm{IC}_{50}$ value of $42.3 \mu \mathrm{g} / \mathrm{mL}$ ) [43], a known antioxidant flavonoid that has reported beneficial health effects [44,45]. Compared to other fruit extracts, such as Cydonia oblonga Miller $\left(\mathrm{IC}_{50}=652 \mu \mathrm{g} / \mathrm{mL}\right)$ [40] and Mangifera indica L. (520 $\mu \mathrm{g} / \mathrm{mL}$ shown $35 \%$ of hemolysis inhibition) [46] the extracts from E. tinifolia and S. lanuginosum presented higher antioxidant capacity.

\subsection{HPLC-DAD-MS/MS Analysis of Phenolic Profiles}

E. tinifolia fruits (Figure 1) contained mainly derivatives of both hydroxybenzoic acids, such as gallic and syringic acids, and hydroxycinnamic acids, such as caffeic acid. However, it was observed that the most abundant compounds in E. tinifolia extract produced, in their mass analysis, pseudomolecular ions at $\mathrm{m} / \mathrm{z} 359$ and 537, which can be attributed to rosmarinic acid (RA) and different lithospermic acid derivatives, respectively (Table 2). Thus, compound 30, which showed a retention time of $51.02 \mathrm{~min}$ (Figure 1), was identified as RA, based on its parent ion $(\mathrm{m} / \mathrm{z} 359)$ and its fragmentation pattern, which was as follows: fragment at $m / z 359$ corresponded to the RA radical ion $\left[\mathrm{M}-\mathrm{H}-\mathrm{C}_{18} \mathrm{H}_{16} \mathrm{O}_{8}\right]^{-}$; fragment at $\mathrm{m} / \mathrm{z}$ 197 , to the radical ion of 3,4-dihydroxyphenylactic acid [M- $\left.-\mathrm{H}_{-} \mathrm{C}_{9} \mathrm{H}_{10} \mathrm{O}_{5}\right]^{-}$; and fragment at $m / z 179$, to the radical ion of caffeic acid $\left[\mathrm{M}-\mathrm{H}-\mathrm{C}_{9} \mathrm{H}_{8} \mathrm{O}_{4}\right]^{-}$. Other fragment ions obtained 
for this compound were fragment at $m / z 161$ ([M- $\left.\mathrm{H}-\mathrm{C}_{9} \mathrm{H}_{7} \mathrm{O}_{3}\right]^{-}$), which can be attributed to acylonium ion and fragment at $m / z 135$, corresponding to $\left[\mathrm{M}-\mathrm{H}_{-} \mathrm{C}_{8} \mathrm{H}_{6} \mathrm{O}_{2}\right]^{-}$. These same fragments were found in compounds 27,28 , and 29, except they showed other signals that corresponded to fragments not determined as sugars. Compounds 20 to 25 were identified as lithospermic acid derivatives, which were isomers since they showed the same pseudomolecular ion at $m / z 625$, with the main fragment ion detected at $m / z 537\left(\mathrm{C}_{27} \mathrm{H}_{22} \mathrm{O}_{12}\right)$, which can be identified as lithospermic acid. Moreover, the fragment ion at $m / z 493[\mathrm{M}-\mathrm{H}]^{-}$ can be formed by the loss of $\mathrm{CO}_{2}(44 \mathrm{Da})$ of the ion at $m / z 537$, whereas fragment ions at $m / z 295\left[\mathrm{M}-\mathrm{H}-\mathrm{CO}_{2}-\mathrm{C}_{9} \mathrm{H}_{10} \mathrm{O}_{5}\right]^{-}$and $m / z 312\left[\mathrm{M}-\mathrm{H}-\mathrm{C}_{9} \mathrm{H}_{8} \mathrm{O}_{4}\right]^{-}$were derived from the ion at $m / z 493$ due to the loss of $\mathrm{C}_{9} \mathrm{H}_{10} \mathrm{O}_{5}$ and $\mathrm{C}_{9} \mathrm{H}_{8} \mathrm{O}_{4}$ fragment ions. These fragments are those reported by Huang et al. [47] for lithospermic acid. Both RA and lithospermic acid derivatives could be relevant for the biological activity of these extracts since RA has been reported to be a compound with significant antioxidant and antineoplastic activity [32], and the lithospermic acid and its mono- and dimethyl esters are known to inhibit adenylate cyclase [48].

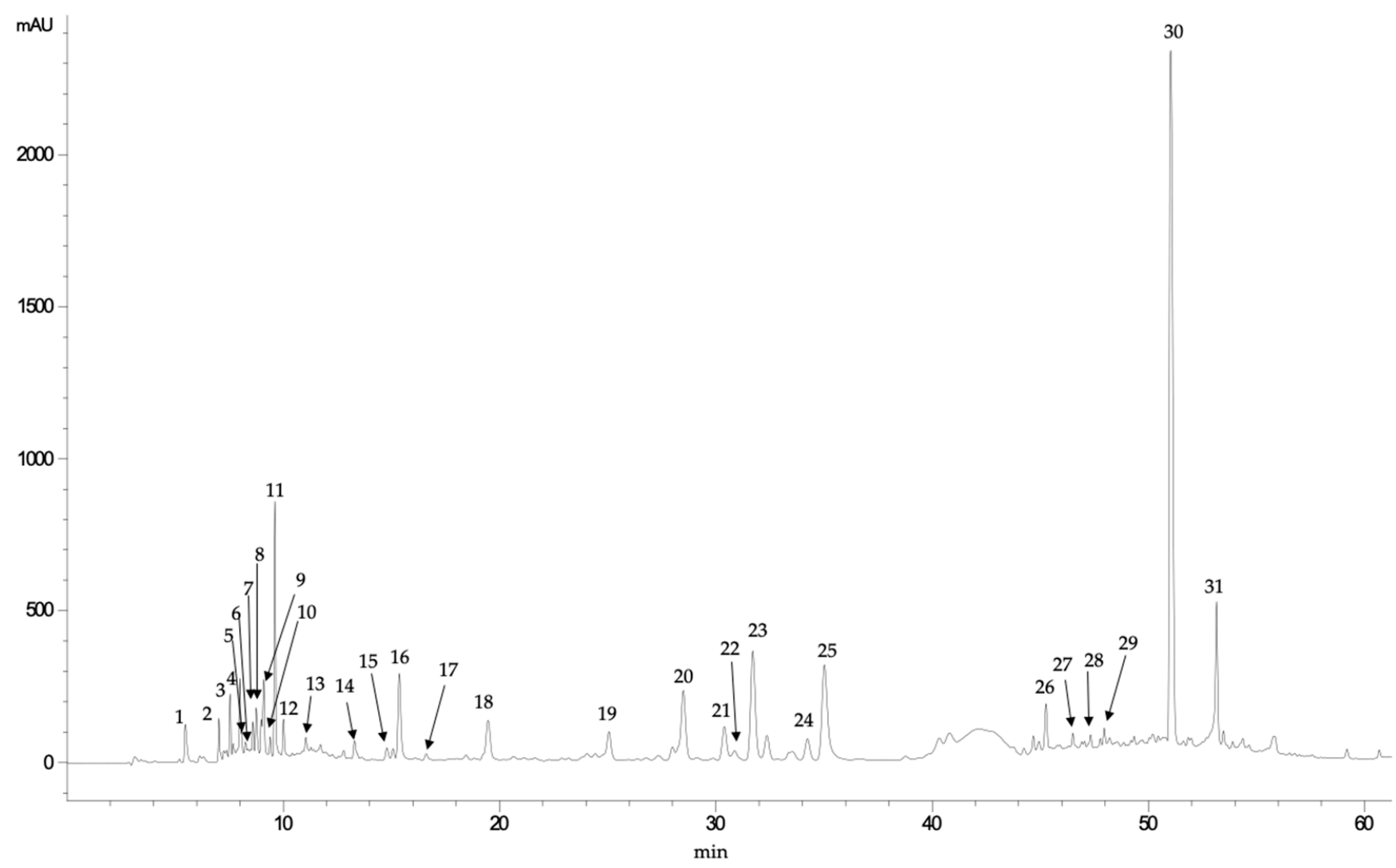

Figure 1. Chromatogram (registered at $280 \mathrm{~nm}$ ) obtained in the analysis of phenolic compounds of pinguica (E. tinifolia).

Table 2. Tentative identification of phenolic compounds of E. tinifolia fruit extract, determined by HPLC-DAD-MS/MS.

\begin{tabular}{cccccc}
\hline Peak & Rt $(\mathbf{m i n})$ & UV Max & {$[\mathbf{M + H}]^{+}$} & MS/MS Fragments & Tentative Identification \\
\hline 1 & 5.46 & 261 & 297.4 & 135 & Unknown \\
2 & 7.01 & 281 & 191.2 & $173,129,111$ & Quinic acid \\
3 & 7.53 & 262 & 373.0 & $311,285,267,249$, & Unknown \\
\hline
\end{tabular}


Table 2. Cont.

\begin{tabular}{|c|c|c|c|c|c|}
\hline Peak & Rt (min) & UV Max & {$[\mathbf{M}+\mathbf{H}]^{+}$} & MS/MS Fragments & Tentative Identification \\
\hline 4 & 7.98 & 252,275 (sh) & 282.5 & 150,133 & Unknown \\
\hline 5 & 8.07 & 301 & 331.3 & 169,125 & Galloil-glucose \\
\hline 6 & 8.58 & 282 & 507.2 & $\begin{array}{c}489,459,293,233 \\
195,131,125,113\end{array}$ & Caffeic acid derivative \\
\hline 7 & 8.74 & 280,314 (sh) & 165.0 & 137 & Unknown \\
\hline 8 & 8.96 & 279 & 507.2 & $233,165,150,125$ & Unknown \\
\hline 9 & 9.08 & 276 & 719.0 & $\begin{array}{c}515,359,197,179 \\
135\end{array}$ & Rosmarinic acid derivative \\
\hline 10 & 9.38 & 272 & 515.0 & $\begin{array}{l}269,251,225,213 \\
179,159,135,109\end{array}$ & Unknown \\
\hline 11 & 9.60 & 278 & 359.0 & $197,179,135$ & Syringic acid hexoside \\
\hline 12 & 10.00 & 281 & 521.0 & $197,179,135$ & Syringic acid dihexoside \\
\hline 13 & 11.03 & 272 & 165.0 & 150,121 & Unknown \\
\hline 14 & 13.28 & 278,320 (sh) & 401.0 & $\begin{array}{c}359,341,297,197 \\
179,135\end{array}$ & Unknown \\
\hline 15 & 14.78 & 278,314 & 365.4 & $323,262,250$ & Unknown \\
\hline 16 & 15.06 & $311,292(\mathrm{sh})$ & 373.0 & $211,179,123$ & Methyl rosmarinate \\
\hline 17 & 15.35 & 281,330 (sh) & 567.0 & 179,135 & Caffeic acid derivative \\
\hline 18 & 19.45 & 291,322 & 179.0 & 135 & Caffeic acid \\
\hline 19 & 25.04 & 276 & 863.0 & $\begin{array}{c}701,521,359,315 \\
297,197,135\end{array}$ & $\begin{array}{c}\text { Syringil-rosmarinic acid } \\
\text { dihexoside }\end{array}$ \\
\hline 20 & 28.48 & 276 & 695.5 & $\begin{array}{c}579,554,537,493,312, \\
295,277,203,135\end{array}$ & $\begin{array}{l}\text { Lithospermic acid } \\
\text { derivative }\end{array}$ \\
\hline 21 & 30.38 & 276 & 695.5 & $\begin{array}{c}579,554,537,493,312 \\
295,277,203,135\end{array}$ & $\begin{array}{c}\text { Lithospermic acid } \\
\text { derivative }\end{array}$ \\
\hline 22 & 31.69 & 276 & 695.5 & $\begin{array}{c}579,554,537,493,312, \\
295,277,203,135\end{array}$ & $\begin{array}{c}\text { Lithospermic acid } \\
\text { derivative }\end{array}$ \\
\hline 23 & 32.35 & 276 & 695.5 & $\begin{array}{c}579,554,537,493,312, \\
295,277,203,135\end{array}$ & $\begin{array}{c}\text { Lithospermic acid } \\
\text { derivative }\end{array}$ \\
\hline 24 & 34.22 & 276 & 695.5 & $\begin{array}{c}579,554,537,493,312, \\
295,277,203,135\end{array}$ & $\begin{array}{c}\text { Lithospermic acid } \\
\text { derivative }\end{array}$ \\
\hline 25 & 35.01 & 276 & 695.5 & $\begin{array}{c}579,554,537,493,312, \\
295,277,203,135\end{array}$ & $\begin{array}{c}\text { Lithospermic acid } \\
\text { derivative }\end{array}$ \\
\hline 26 & 45.25 & 275,330 (sh) & 597.4 & $\begin{array}{c}579,509,491,355,337 \\
329,311,293,267,239 \\
197,179,135,109\end{array}$ & Unknown \\
\hline 27 & 46.49 & 284,320 & 861.5 & $\begin{array}{c}843,817,655,521,501 \\
475,457,383,359,339 \\
323,197,179,135\end{array}$ & Rosmarinic acid derivative \\
\hline 28 & 47.31 & 285,318 & 521.0 & $359,197,179,161,135$ & Rosmarinic acid-hexoside \\
\hline 29 & 47.94 & 283,327 & 521.0 & $359,197,179,161,135$ & Rosmarinic acid-hexoside \\
\hline 30 & 51.02 & $330,290(\mathrm{sh})$ & 359.0 & 197, 179, 161, 135 & Rosmarinic acid \\
\hline 31 & 53.13 & 278 & 537.0 & $\begin{array}{c}493,359,295,277,203 \\
185,159,135,109\end{array}$ & Lithospermic acid A \\
\hline
\end{tabular}

sh = shoulder.

In the case of S. lanoginosum fruits (Figure 2), although different hydroxybenzoic acids (such us gallic and protocatechuic acids) and hydroxycinnamic acids (such as coumaric and ferulic acids) were identified, the main family of phenolic compounds identified was flavonols. Thus, mainly quercetin and myricetin glycosides and their corresponding nonglycoside forms were identified in these fruits (Table 3). The structure of flavonoids often results in substituents such as hydroxyl, methyl, and methoxyl groups. Therefore, in the MS/MS analysis, fragment ions are usually derived from the loss of $\mathrm{CO}(28 \mathrm{Da}), \mathrm{H}_{2} \mathrm{O}(18 \mathrm{Da})$ or $\mathrm{CO}_{2}$ (44 Da) molecules, as well as the fragment ions of substituents [49]. In addition, the retro-Diels-Alder (RDA) fragmentation is a common fragmentation pattern in flavonoids. Compound 34, which showed a pseudomolecular ion $[\mathrm{M}-\mathrm{H}]^{-}$at $\mathrm{m} / \mathrm{z} 301$, was identified as quercetin $\left(\mathrm{C}_{15} \mathrm{H}_{10} \mathrm{O}_{7}\right)$. The fragment ion at $\mathrm{m} / z 273[\mathrm{M}-\mathrm{H}-\mathrm{CO}]^{-}$was derived from the 
loss of a $\mathrm{CO}(28 \mathrm{Da})$ and that at $m / z 179\left(\left[\mathrm{M}-\mathrm{H}-\mathrm{C}_{7} \mathrm{H}_{6} \mathrm{O}_{2}\right]^{-}\right)$can be explained by the RDA fragmentation. Subsequently, fragment ions at $m / z 151\left[\mathrm{M}-\mathrm{H}-\mathrm{C}_{7} \mathrm{H}_{6} \mathrm{O}_{2}-\mathrm{CO}\right]^{-}$originated from the ion at $\mathrm{m} / \mathrm{z} 179$ by the loss of a CO $(28 \mathrm{Da})$ [46]. Compound 22 was the main compound, and it was identified as quercetin glucoside, showing a pseudomolecular ion at $m / z 463$, whose fragmentation produced the ion at $m / z 301\left[\mathrm{M}-\mathrm{HC}_{15} \mathrm{H}_{10} \mathrm{O}_{7}\right]^{-}$after the loss of a glucoside molecule (162 Da). Similarly, compounds 23 and 24 also showed fragment ions at $m / z 301$ in their MS/MS analysis, formed after losing a glucuronic acid (176 Da). In contrast, compounds 25 and 26 were identified as quercetin-pentoside because of detecting the same ion fragment $(\mathrm{m} / \mathrm{z}$ 301) after the loss of $132 \mathrm{Da}$ (which can be attributed to a pentose moiety). Quercetin derivatives and, mainly quercetin glucoside, can be relevant for the biological activity of S. lanoginosum fruits, since this compound has been shown to protect DNA and erythrocytes from oxidative damage and exhibited anticancer activity [50].

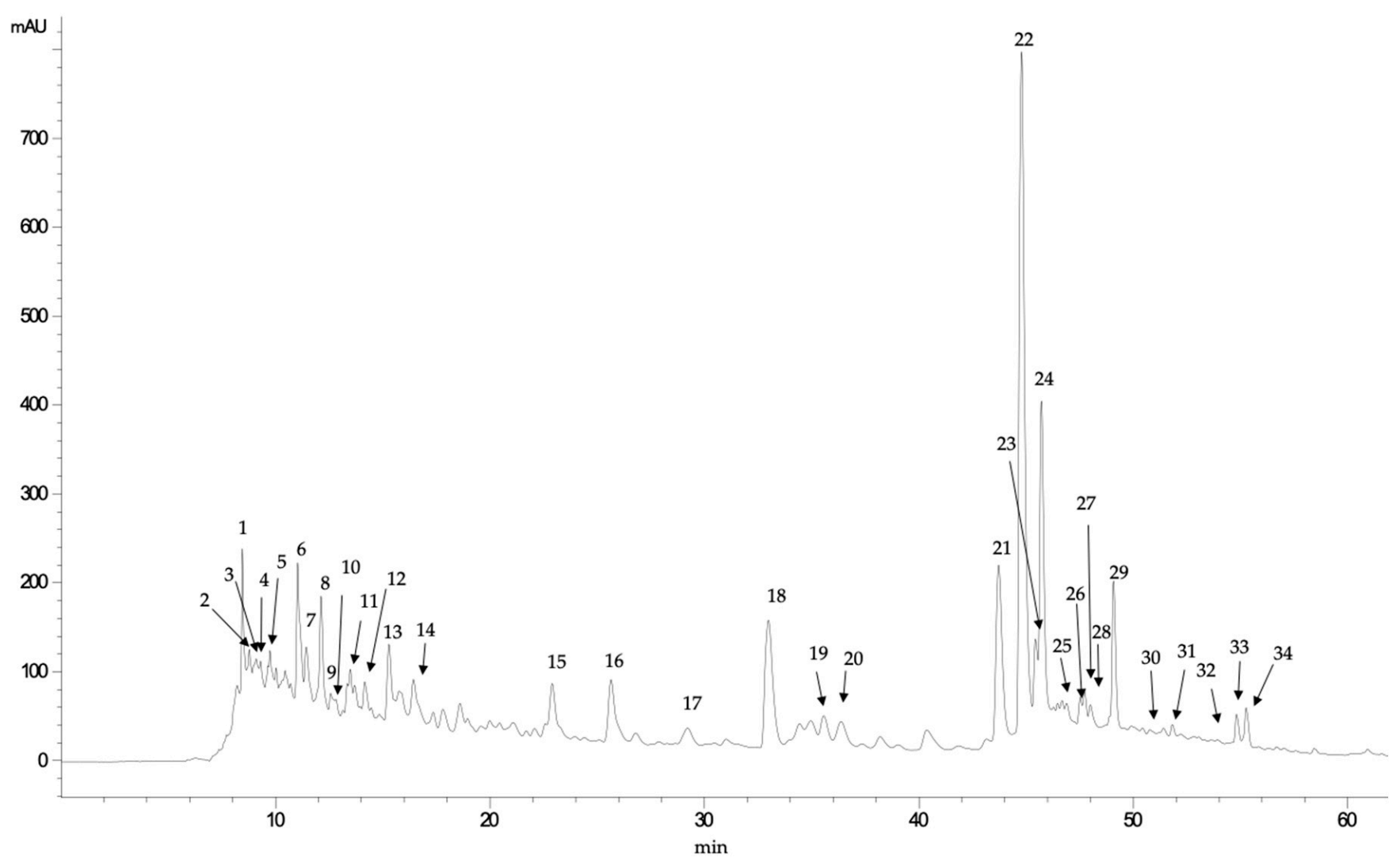

Figure 2. Chromatogram (registered at $280 \mathrm{~nm}$ ) obtained in the analysis of phenolic compounds of coma (S. lanoginosum).

Table 3. Tentative identification of phenolic compounds of S. lanoginosum fruit extract by HPLC-DAD electrospray ionization (ESI)-MS/MS.

\begin{tabular}{cccccc}
\hline Peak & Rt $($ Min) & UV Max & {$[\mathbf{M + H}]^{+}$} & MS/MS Fragments & Tentative Identification \\
\hline 1 & 8.44 & 272 & 169.1 & 125,113 & Gallic acid \\
2 & 8.76 & 245 & 137.0 & & p-hydroxybenzoic acid \\
3 & 8.89 & 278 & 329.3 & $167,151,109$ & Unknown \\
4 & 9.30 & 282 & 331.2 & 169,125 & Unknown \\
5 & 9.74 & 283 & 315.2 & 152,108 & Unknown \\
6 & 11.02 & $259-293$ & 153.1 & 123,109 & Protocatechuic acid \\
7 & 11.43 & $286,315(\mathrm{sh})$ & 461.0 & $351,323,248,233,193$ & Ferulic acid derivative \\
8 & 12.11 & $285,324(\mathrm{sh})$ & 463.3 & $283,272,255,175,163$ & Unknown \\
9 & 13.48 & 295,311 & 487.4 & $187,163,145,119$ & Coumaric dihexoside \\
\hline
\end{tabular}


Table 3. Cont.

\begin{tabular}{|c|c|c|c|c|c|}
\hline Peak & Rt (Min) & UV Max & {$[\mathrm{M}+\mathrm{H}]^{+}$} & MS/MS Fragments & Tentative Identification \\
\hline 10 & 14.15 & $256,311(\mathrm{sh})$ & 435.2 & $241,193,153$ & Ferulic acid derivative \\
\hline 11 & 15.26 & 255,335 & 311.3 & $\begin{array}{c}249,231,205,187,161,14 \\
147,135,121\end{array}$ & Unknown \\
\hline 12 & 15.82 & 303 & 421.2 & 241 & Unknown \\
\hline 13 & 16.41 & 280 & 417.1 & $399,227,167,153$ & Unknown \\
\hline 14 & 17.77 & 281,310 (sh) & 387.0 & 163 & Coumaric acid derivative \\
\hline 15 & 22.88 & $267,327(\mathrm{sh})$ & 241.2 & $197,168,141,130$ & Phenolic acid derivative \\
\hline 16 & 25.63 & $262,331(\mathrm{sh})$ & 295.0 & $251,189,137,121$ & Phenolic acid derivative \\
\hline 17 & 29.23 & 307,290 (sh) & 163.0 & 119 & Coumaric acid \\
\hline 18 & 32.95 & $255,351,301(\mathrm{sh})$ & 755.5 & $\begin{array}{c}609,489,355,343,325 \\
301,271,179\end{array}$ & $\begin{array}{l}\text { Quercetin glucoside } \\
\text { dirhamnoside }\end{array}$ \\
\hline 19 & 34.82 & 354,300 (sh) & 479.0 & $317,287,271,179,151$ & Myricetin glucoside \\
\hline 20 & 35.54 & $254,352,302(\mathrm{sh})$ & 771.0 & 301 & $\begin{array}{l}\text { Quercetin diglucoside } \\
\text { rhamnoside }\end{array}$ \\
\hline 21 & 43.66 & $256,353,305(\mathrm{sh})$ & 609.4 & $\begin{array}{c}343,301,271,255,179 \\
151\end{array}$ & $\begin{array}{c}\text { Quercetin } \\
\text { neohesperidoside }\end{array}$ \\
\hline 22 & 44.73 & $256,355,301(\mathrm{sh})$ & 463.4 & $\begin{array}{c}306,301,271,255,248 \\
179,151,121\end{array}$ & Quercetin glucoside \\
\hline 23 & 45.40 & $257,342,302(\mathrm{sh})$ & 477.0 & 301,151 & Quercetin glucuronide \\
\hline 24 & 45.68 & $256,354,300(\mathrm{sh})$ & 477.0 & $301,179,151$ & Quercetin glucuronide \\
\hline 25 & 46.68 & $267,359(\mathrm{sh})$ & 433.8 & $301,271,179,151$ & Quercetin pentoside \\
\hline 26 & 47.52 & 255,351 & 433.9 & $301,271,256,180,152$ & Quercetin pentoside \\
\hline 27 & 47.71 & 264,349 & 447.9 & $285,256,227,151$ & Kaempferol glucoside \\
\hline 28 & 47.99 & $284,340(\mathrm{sh})$ & 436.0 & $346,316,274,167,123$ & Unknown \\
\hline 29 & 49.06 & 257,347 & 447.0 & $301,273,257,179,151$ & Kaempferol glucoside \\
\hline 30 & 50.85 & 371 & 317.0 & $179,151,138$ & Myricetin \\
\hline 31 & 51.18 & $327,287(\mathrm{sh})$ & 359.0 & $197,179,161,135$ & Rosmarinic acid \\
\hline 32 & 54.79 & $264,316,356(\mathrm{sh})$ & 609.8 & $463,301,151$ & Quercetin rutinoside \\
\hline 33 & 55.25 & $251,330,300(\mathrm{sh})$ & 639.8 & $477,463,316,300$ & $\beta$-hydroverbascoside \\
\hline 34 & 57.00 & 370,300 (sh) & 301.2 & $\begin{array}{c}273,229,179,161 \\
151,121\end{array}$ & Quercetin \\
\hline
\end{tabular}

$\mathrm{sh}=$ shoulder.

\subsection{Digestive Enzymes Inhibition}

\subsubsection{Inhibition of $\alpha$-Glucosidase}

Currently, only a few $\alpha$-glucosidase inhibitors, such as acarbose and voglibose, have been approved to treat diabetes, and their structures are mainly composed of sugar moieties [51]. Thus, many studies have been focused on searching for alternative $\alpha$-glucosidase inhibitors with non-sugar core structure, particularly the polyphenols, due to their abundant availability in nature and their promising biological activities [52]. In the $\alpha$-glucosidase assay, E. tinifolia and S. lanuginosum extracts showed high inhibitory activities with $\mathrm{IC}_{50}$ values of 0.17 and $0.21 \mathrm{mg} / \mathrm{mL}$, respectively (Table 4). Under the same experimental conditions, the positive control acarbose presented an $\mathrm{IC}_{50}$ value of $0.13 \mathrm{mg} / \mathrm{mL}$. LopezMartinez et al. [53] evaluated onions extracts for the inhibition of $\alpha$-glucosidase activity and found that white variety inhibited more than $50 \%$ at $0.7 \mathrm{mg} / \mathrm{mL}$. Hogan et al. [54] reported that red grape extract $(1.5 \mathrm{mg} / \mathrm{mL})$ inhibited $47 \%$ of $\alpha$-glucosidase enzyme activity, and the inhibition potency was significantly higher than the white grape extract they tested $(1.5 \mathrm{mg} / \mathrm{mL})$, which only inhibited $\alpha$-glucosidase activity by $39 \%$. This research shows that an extract with more phenolics and anthocyanins is a better $\alpha$-glucosidase inhibitor. Furthermore, it has been demonstrated that quercetin and kaempferol in S. lanuginosum and rosmarinic acid present on E. tinifolia are effective inhibitors of this enzyme [55,56]. Considering these compounds as the main polyphenols of extracts activity, the mechanism of $\alpha$-glucosidase inhibition by wild fruit extracts could be due to the non-competitive or mixed-type interactions that polyphenols such as quercetin, kaempferol [57-59], and rosmarinic acid [60] maintain with the enzyme. Further studies must be done to determine 
the mechanism of action of S. lanuginosum and E. tinifolia extracts. These evidences emphasize the possible application of wild fruits or their derivatives in the design of diabetes treatments.

Table 4. Inhibition of digestive enzymatic and antiproliferative activity by E. tinifolia and S. lanuginosum fruit extracts.

\begin{tabular}{|c|c|c|c|c|c|c|c|}
\hline \multirow{2}{*}{ Sample } & \multicolumn{7}{|c|}{ Half Maximal Inhibitory Concentration [mg/mL] } \\
\hline & $\alpha-$ Glu & $\alpha$-Amy & Lipase & MCF-7 & HeLa & HT-29 & * RBCs \\
\hline S. lanuginosum & $0.21 \pm 0.3^{\mathrm{a}}$ & $>5$ & $>5$ & $1.99 \pm 0.3^{\mathrm{a}}$ & $3.22 \pm 0.8^{\mathrm{a}}$ & $1.97 \pm 0.2^{\mathrm{a}}$ & $>5$ \\
\hline E. tinifolia & $0.17 \pm 0.1^{\mathrm{a}, \mathrm{b}}$ & $>5$ & $>5$ & $0.99 \pm 0.01^{\mathrm{b}}$ & $1.36 \pm 0.2^{b}$ & $0.82 \pm 0.09^{b}$ & $>5$ \\
\hline ** Control & $0.13 \pm 0.2^{\mathrm{b}}$ & $0.97 \pm 0.08$ & $0.17 \pm 0.20$ & $0.013 \pm 0.001^{\mathrm{c}}$ & $0.011 \pm 0.002^{c}$ & $0.015 \pm 0.001^{\mathrm{c}}$ & ND \\
\hline
\end{tabular}

${ }^{*}$ RBCs $=$ Red blood cells $=$ Erythrocytes. ${ }^{* *}$ Acarbose was used on $\alpha$-glucosidase and $\alpha$-amylase assays, orlistat on Lipase inhibition and taxol against cancer cells lines. $n=3$, literals $(\mathrm{a}-\mathrm{c}$ ) on each column show significant differences among treatments, according to Tukey's test $(p<0.05)$. ND: not determined.

\subsubsection{Inhibition of $\alpha$-Amylase}

$\alpha$-Amylase enzyme is one of the key enzymes in the human digestive system, which degrades starch to monosaccharides and causes the rise of blood glucose [61]. Natural amylase inhibitors offer an attractive therapeutic approach to the treatment of postprandial hyperglycemia by decreasing glucose released from starch. Extracts of E. tinofolia and S. lanuginosum slightly inhibited amylase activity at concentrations of $5 \mathrm{mg} / \mathrm{mL}$ (30.95\% and $26.06 \%$ respectively) with $\mathrm{IC}_{50}$ values $>5 \mathrm{mg} / \mathrm{mL}$. In other studies, polyphenol-rich extracts from different types of berries inhibited $\alpha$-amylase in vitro, and the most effective were from raspberry and rowanberry ( $\mathrm{IC}_{50}$ values of 21 and $4.5 \mu \mathrm{g} / \mathrm{mL}$, respectively). Thus, strawberry and raspberry extracts were more effective amylase inhibitors than blueberry and blackcurrant [62]. Other authors observed that the extent of inhibition of $\alpha$-amylase was related to appreciable amounts of soluble tannins [62]. Our fruits extracts are poor in tannins content, and it may explain the low inhibitory enzymatic activity.

\subsubsection{Inhibition of Pancreatic Lipase}

Both fruit extracts showed no activity against lipase, while positive control Orlistat showed $\mathrm{IC}_{50}$ value of $0.04 \mu \mathrm{g} / \mathrm{mL}$ (Table 4). These results agree with a study of $P$. andina extracts that did not inhibit lipase activity [41]. The inhibition of lipase has been associated with higher content of tannins more than phenolic compounds [41]. This result could explain the absence of inhibition towards the lipase enzyme.

\subsection{Antiproliferative Activity}

Many studies reported the in vivo and in vitro effectiveness of phenolic compounds of fruits as anticancer. The bioactive compounds have significant anticancer effects through various complementary mechanisms of action, including the induction of metabolizing enzymes and the modulation of gene expression; and their impact on cell proliferation, apoptosis, and subcellular signaling pathway $[63,64]$.

Antiproliferative activity of E. tinifolia and S. lanuginosum extracts were evaluated using three human cancer cell lines, HeLa (cervicouterine adenocarcinoma), MCF-7 (breast adenocarcinoma) and HT-29 (colon adenocarcinoma). Results showed that MCF-7 cell line was the most sensitive to the E. tinifolia extract, and the S. lanuginosum extract was against HT-29 cell line. The effect of E. tinifolia and S. lanuginosum extracts on cancer cell lines was dose-dependent and varied with the cell type and extract concentration. The concentration of $2 \mathrm{mg} / \mathrm{mL}$ of both extracts was the most effective. Nevertheless, $E$. tinifolia had the strongest effect on the three cell types. It revealed a marked decrease in the viability of the cancer cell lines after treatment. The $50 \%$ growth inhibition $\left(\mathrm{IC}_{50}\right)$ of cells exposed to E. tinifolia was $0.99,1.36$ and $0.82 \mathrm{mg} / \mathrm{mL}$, and for S. lanuginosum were $1.99,3.22$, and $1.97 \mathrm{mg} / \mathrm{mL}$ for MCF-7, HeLa, and HT-29 cells, respectively (Table 4). It can be suggested that a wide range of phenolic compounds in the extract contributed to their cytotoxic activity. Al Hasani et al. [65] evaluated the antiproliferative activity for MCF-7 cells of Sideroxylon mascatense fruit extract and showed higher activity than E. tinifolia and 
S. lanuginosum extracts $\left(\mathrm{IC}_{50}\right.$ value of $64 \mu \mathrm{g} / \mathrm{mL}$ ). Though the extracts of Pyracantha coccinea $\left(\mathrm{IC}_{50} 1.2 \mathrm{mg} / \mathrm{mL}\right.$ ) and Zosima absinthifolia $\left(\mathrm{IC}_{50} 1.5 \mathrm{mg} / \mathrm{mL}\right.$ ) had less antiproliferative activity than E. tinifolia for HeLa cells $[66,67]$. The main phenol compound found on $E$. tinifolia extract was rosmarinic acid, and it could be responsible for the antiproliferative activity, as described by Niu et al. [68]. They compared the antiproliferative activity of Rosmarinus officinalis with rosmarinic acid and concluded that rosmarinic acid was more active than the plant extract against HeLa cells.

Breast cancer is the most frequently diagnosed cancer in women. An alternative strategy to reduce the risk of cancer is through dietary modification. E. tinifolia and S. lanuginosum extracts showed better antiproliferative activity against MCF-7 cells than an apple extract $\left(\mathrm{IC}_{50}=70.7 \mathrm{mg} / \mathrm{mL}\right)$ [69]. Moreover, quercetin glucoside (QG) exhibited significant antiproliferative activity against MCF-7 cells. The $\mathrm{EC}_{50}$ value of QG in inhibiting MCF-7 cell growth was $46.4 \mu \mathrm{M}$ [69]. This flavonoid is the most abundant phenolic compound in S. lanuginosum extract and could be responsible for inhibiting MCF-7 cells.

Phenolic compounds of E. tinifolia and S. lanuginosum inhibited proliferation of colon cancer cells HT-29. Similar effects have been shown of Borago extracts with $\mathrm{CI}_{50}$ values within the $250-300 \mu \mathrm{g} / \mathrm{mL}$ range after $72 \mathrm{~h}$ of cell exposure. Like in E. tinifolia, rosmarinic acid was the main phenolic compound detected in all Borago taxa [70]. In another study, the main phenolic compounds in Rabbiteye blueberry could inhibit HT-29 cancer cell proliferation and induce apoptosis. The phenolic acid fraction showed antiproliferation activities with an $\mathrm{IC}_{50}$ of $\sim 1000 \mu \mathrm{g} / \mathrm{mL}$ [71].

\section{Conclusions}

Sideroxylon lanuginosum (coma) presented the higher content of total flavonoid $(21.4 \pm 1.5 \mathrm{mg} \mathrm{GAE} / 100 \mathrm{~g} \mathrm{FW})$; the most abundant flavonoid detected was the quercetin glucoside. In comparison, Ehretia tinifolia (pinguica) had higher total phenol content $(64.7 \pm 2.6 \mathrm{mg} \mathrm{GAE} / 100 \mathrm{~g} \mathrm{FW})$, and the most abundant phenolic detected was rosmarinic acid. These major compounds could be related to the interesting biological activity of both extracts. E. tinifolia showed the best effect in antioxidant/antiradical activity both in vitro $\left(\mathrm{EC}_{50}=0.32 \pm 0.03 \mathrm{mg} / \mathrm{mL} ; 4134 \pm 9.7 \mu \mathrm{M} \mathrm{TE} / \mathrm{g}\right.$ dry extract $)$, ex vivo assay $\left(\mathrm{IC}_{50}=58.55 \pm\right.$ $2.4 \mu \mathrm{g} / \mathrm{mL}$ ), and the inhibition of $\alpha$-glucosidase $\left(\mathrm{IC}_{50}=0.17 \pm 0.1 \mathrm{mg} / \mathrm{mL}\right.$ ). Additionally, the extract of E. tinifolia showed a better effect on the growth inhibition of cancer cells, particularly against those of the human colon $\left(\mathrm{IC}_{50}=0.82 \pm 0.09 \mathrm{mg} / \mathrm{mL}\right)$ and breast cancer $\left(\mathrm{IC}_{50}=0.99 \pm 0.01 \mathrm{mg} / \mathrm{mL}\right)$. These results contribute to the scant information available on these wild fruits and contribute to revalue their use as a natural source of antioxidants with potential therapeutic application in diseases caused by free radicals. Further investigations using animal models are needed to confirm the beneficial effects of the studied extracts as supplementary treatments for oxidative diseases.

Author Contributions: Bioassays, I.N.M.-G.; Conceptualization, I.N.M.-G. and E.V.-V.; Antiproliferative methodology and supervision, I.E.C.-T. and P.C.-R.; Antioxidant assays and supervision, J.F.A.-Z. and J.M.-M.; Enzymatic inhibition assays and supervision, E.V.-V.; Phenolic composition, I.G.-E. and M.O.-A.; Project administration, E.V.-V.; I.N.M.-G., and E.V.-V. writing-review and editing. All authors have read and agreed to the published version of the manuscript.

Funding: This research study was funded by PAICYT-UANL: CN1581-21.

Acknowledgments: Author Imelda N. Monroy-García thanks CONACyT (Mexico) for her doctoral scholarship no.701994, MEXICO, and the Salamanca University (USAL, Spain) for technical support.

Conflicts of Interest: We declare that we have no conflict of interest. 


\section{References}

1. Jiménez-Aspee, F.; Thomas-Valdés, S.; Schulz, A.; Ladio, A.; Theoduloz, C.; Schmeda-Hirschmann, G. Antioxidant activity and phenolic profiles of the wild currant Ribes magellanicum from Chilean and Argentinean Patagonia. Food Sci. Nutr. 2015, 4, 595-610. [CrossRef]

2. Turner, N.J.; Łuczaj, L.J.; Migliorini, P.; Pieroni, A.; Dreon, A.L.; Sacchetti, L.E.; Paoletti, M.G. Edible and Tended Wild Plants, Traditional Ecological Knowledge and Agroecology. Crit. Rev. Plant Sci. 2011, 30, 198-225. [CrossRef]

3. Bvenura, C.; Sivakumar, D. The role of wild fruits and vegetables in delivering a balanced and healthy diet. Food Res. Int. 2017, 99, 15-30. [CrossRef] [PubMed]

4. Hadjichambis, A.C.; Paraskeva-Hadjichambi, D.; Della, A.; Giusti, M.E.; De Pasquale, C.; Lenzarini, C.; Censorii, E.; GonzalesTejero, M.R.; Sanchez-Rojas, C.P.; Ramiro-Gutierrez, J.M.; et al. Wild and semi-domesticated food plant consumption in seven circum-Mediterranean areas. Int. J. Food Sci. Nutr. 2008, 59, 383-414. [CrossRef] [PubMed]

5. Tardío, J.; Pardo-De-Santayana, M.; Morales, R. Ethnobotanical review of wild edible plants in Spain. Bot. J. Linn. Soc. 2006, 152, 27-71. [CrossRef]

6. Miller, J.S. A Revision of the New World Species of Ehretia (Boraginaceae). Ann. Mo. Bot. Gard. 1989, 76, 1050. [CrossRef]

7. Monroy-Ortiz, C.; Monroy, R. Las Plantas Compañeras de Siempre. La Experiencia en Morelos; Universidad Autónoma del Estado de Morelos: Cuernavaca, Mexico, 2006.

8. Martínez, M. Catálogo de Nombres Vulgares y Científicos de Plantas Mexicanas; Fondo de Cultura Económica: Ciudad de México, México, 1979; pp. 93-1071.

9. Benítez-Badillo, G.; Pulido-Salas, M.T.P.; Equihua-Samora, M. Árboles Multiusos Nativos de Veracruz para Reforestación, Restauración y Plantaciones; Instituto de Ecología, A.C., Sigolfo, Conafor: Xalapa, México, 2008; 108p.

10. Pío-León, J.F.; Díaz-Camacho, S.P.; López, M.G.; Montes-Avila, J.; López-Angulo, G.; Delgado-Vargas, F. Physicochemical, nutritional, and antioxidant characteristics of the fruit of Ehretia tinifolia. Rev. Mex. Biodivers. 2012, 83, 273-280. [CrossRef]

11. Cowan, R.S.; Little, E.L. The Audubon Society Field Guide to North American Trees: Eastern Region. TAXON 1981, $30,548$. [CrossRef]

12. Bahadoran, Z.; Mirmiran, P.; Azizi, F. Dietary polyphenols as potential nutraceuticals in management of diabetes: A review. J. Diabetes Metab. Disord. 2013, 12, 43. [CrossRef]

13. Tsao, R. Chemistry and Biochemistry of Dietary Polyphenols. Nutrients 2010, 2, 1231-1246. [CrossRef]

14. Pandey, K.B.; Rizvi, S.I. Plant Polyphenols as Dietary Antioxidants in Human Health and Disease. Oxidative Med. Cell. Longev. 2009, 2, 270-278. [CrossRef]

15. Yang, C.S.; Landau, J.M.; Huang, M.-T.; Newmark, H.L. Inhibition of Carcinogenesis by Dietary Polyphenolic Compounds. Annu. Rev. Nutr. 2001, 21, 381-406. [CrossRef]

16. Moein, S. Polyphenols and cancer: A review. Mol. Med. J. 2015, 1, 6-12.

17. Wu, X. Rosa Roxburghii tratt Fruit and Green Jujube Beverage and Preparation Method Thereof. CN106578777A, 26 April 2017.

18. Wang, C.; Li, J.; Li, Q.; Song, Q. A Kind of Stauntonvine Pulp Fruitcake and Preparation Method Thereof. CN108094661A, 1 June 2018.

19. Yichun Zhongzhi Dashanwang Liquor Industry Co Ltd. Wild Indigo Naturalis-Cowberry Beer. CN105524756A, 27 April 2016.

20. Foshan Huili Cosmetics Science and Technology Co Ltd. Post-Solar Restorative Composition. CN108272729A, 13 July 2018.

21. Liu, J. Wild Cherry Berry Diet Therapy Drink and Preparation Method Thereof. CN106983058A, 28 July 2017.

22. Derosa, G.; Romano, D.; D'Angelo, A.; Maffioli, P. Berberis aristata/Silybum marianum fixed combination (Berberol $\left.{ }^{\circledR}\right)$ effects on lipid profile in dyslipidemic patients intolerant to statins at high dosages: A randomized, placebo-controlled, clinical trial. Phytomedicine 2015, 22, 231-237. [CrossRef]

23. Viveros-Valdez, E.; Jaramillo-Mora, C.; Oranday-Cárdenas, A.; Morán-Martínez, J.; Carranza-Rosales, P. Antioxidant, cytotoxic and alpha-glucosidase inhibition activities from the Mexican berry Anacahuita (Cordia boissieri). Arch. Latinoam. Nutr. 2016, 66, 211-218.

24. Singleton, V.; Rossi, J. Colorimetry of Total Phenolic Compounds with Phosphomolybdic-Phosphotungstic Acid Reagents. Am. J. Enol. Vitic. 1965, 16, 144-158.

25. Zhishen, J.; Mengcheng, T.; Jianming, W. The determination of flavonoid contents in mulberry and their scavenging effects on superoxide radicals. Food Chem. 1999, 64, 555-559. [CrossRef]

26. Braca, A.; Sortino, C.; Politi, M.; Morelli, I.; Mendez, J. Antioxidant activity of flavonoids from Licania licaniaeflora. J. Ethnopharmacol. 2002, 79, 379-381. [CrossRef]

27. Gupta, R.; Sharma, M.; Lakshmy, R.; Prabhakaran, D.; Reddy, K.S. Improved method of total antioxidant assay. Indian J. Biochem. Biophys. 2009, 46, 126-129.

28. Silva-Beltrán, N.P.; Balderrama-Carmona, A.P.; López-Cuevas, O.; Portela-Márquez, M.A.; Umsza Guez, M.A.; López-Mata, M.A. Antioxidant and antimicrobial activity of Barchata (Zizhipus Obtusifolia). Revista Ciencias. 2019, 6, e523. [CrossRef]

29. Kaskoos, R.A. In-vitro $\alpha$-glucosidase inhibition and antioxidant activity of methanolic extract of Centaurea calcitrapa from Iraq. Am. J. Essent. Oil. Nat. Prod. 2013, 1, 122-125.

30. Shuda, P.; Zinjarde, S.S.; Bhargava, S.Y.; Kumar, A.R. Potent $\alpha$-amylase inhibitory activity of Indian Ayurvedic medicinal plants. BMC Complement. Altern. Med. 2011, 11, 5. [CrossRef] 
31. Maqsood, M.; Ahmed, D.; Atique, I.; Malik, W. Lipase inhibitory activity of Lagenaria siceraria fruit as a strategy to treat obesity. Asian Pac. J. Trop. Med. 2017, 10, 305-310. [CrossRef]

32. Viveros-Valdez, E.; Rivas-Morales, C.; Oranday-Cárdenas, A.; Castro-Garza, J.; Carranza-Rosales, P. Antiproliferative Effect from the Mexican Poleo (Hedeoma drummondii). J. Med. Food 2010, 13, 740-742. [CrossRef]

33. Cittadini, M.C.; García-Estévez, I.; Escribano-Bailón, M.T.; Rivas-Gonzalo, J.C.; Valentich, M.A.; Repossi, G.; Soria, E.A. Modulating activity of phenolic compounds from American plant infusions on fatty acid-related interleukin-6 release in glial cells. Nutr. Cancer 2018, 70, 267-277. [CrossRef] [PubMed]

34. Turker, G. Free radical scavenging activity and phenolic content of edible wild fruits from Kazdagi (Ida Mountains), Turkey. J. Med. Plants Res. 2012, 6. [CrossRef]

35. Schmeda-Hirschmann, G.; Feresin, G.; Tapia, A.; Hilgert, N.; Theoduloz, C. Proximate composition and free radical scavenging activity of edible fruits from the Argentinian Yungas. J. Sci. Food Agric. 2005, 85, 1357-1364. [CrossRef]

36. Jiménez-Aspee, F.; Quispe, C.; Soriano, M.D.P.C.; Gonzalez, J.F.; Hüneke, E.; Theoduloz, C.; Schmeda-Hirschmann, G. Antioxidant activity and characterization of constituents in copao fruits (Eulychnia acida Phil., Cactaceae) by HPLC-DAD-MS/MSn. Food Res. Int. 2014, 62, 286-298. [CrossRef]

37. Ikram, E.H.K.; Eng, K.H.; Jalil, A.M.M.; Ismail, A.; Idris, S.; Azlan, A.; Nazri, H.S.M.; Diton, N.A.M.; Mokhtar, R.A.M. Antioxidant capacity and total phenolic content of Malaysian underutilized fruits. J. Food Compos. Anal. 2009, 22, 388-393. [CrossRef]

38. Recuenco, M.; Lacsamana, M.; Hurtada, W.; Sabularse, V. Total Phenolic and Total Flavonoid Contents of Selected Fruits in the Philippines. Philipp. J. Sci. 2016, 145, 275-281.

39. Goulas, V.; Georgiou, E. Utilization of Carob Fruit as Sources of Phenolic Compounds with Antioxidant Potential: Extraction Optimization and Application in Food Models. Foods 2019, 9, 20. [CrossRef]

40. Magalhães, A.S.; Silva, B.M.; Pereira, J.A.; Andrade, P.; Valentão, P.; Carvalho, M. Protective effect of quince (Cydonia oblonga Miller) fruit against oxidative hemolysis of human erythrocytes. Food Chem. Toxicol. 2009, 47, 1372-1377. [CrossRef] [PubMed]

41. Jiménez-Aspee, F.; Theoduloz, C.; Pormetter, L.; Mettke, J.; Ávila, F.; Schmeda-Hirschmann, G. Andean Prumnopitys Andina (Podocarpacae) Fruit Extracts: Characterization of Secondary Metabolites and Potential Cytoprotective Effect. Molecules 2019, 24, 4028. [CrossRef] [PubMed]

42. Ruíz-Rodriguez, B.M. Frutos Silvestres de uso Tradicional en la Alimentación: Evaluación de su Valor Nutricional, Compuestos Bioactivos y Capacidad Antioxidante. Ph.D. Thesis, Universidad Complutense de Madrid, Madrid, Spain, 2014.

43. Mitjans, M.; Martínez, V.; del Campo, J.; Abajo, C.; Lozano, C.; Torres, J.; Vinardell, M.P. Novel epicatechin derivatives with antioxidant activity modulate interleukin-1 $\beta$ release in lipopolysaccharide-stimulated human blood. Bioorg. Med. Chem. Lett. 2004, 14, 5031-5034. [CrossRef]

44. Prakash, M.; Basavaraj, B.V.; Murthy, K.C. Biological functions of epicatechin: Plant cell to human cell health. J. Funct. Foods 2018, 52, 14-24. [CrossRef]

45. Shay, J.; Elbaz, H.; Lee, I.; Zielske, S.P.; Malek, M.H.; Hüttemann, M. Molecular Mechanisms and Therapeutic Effects of (-)Epicatechin and Other Polyphenols in Cancer, Inflammation, Diabetes, and Neurodegeneration. Oxidative Med. Cell. Longev. 2015, 2015, 1-13. [CrossRef]

46. Vega-Vega, V. Enriquecimento de la Capacidad Antioxidante y Proteción Antimicrobiana del Mango Fresco Cortado Aplicando Compuestos Fenólicos de sus Subproductos. Master's Thesis, CIAD, Hermosillo, México, August 2011.

47. Huang, G.; Liang, J.; Chen, X.; Lin, J.; Wei, J.; Huang, D.; Zhou, Y.; Sun, Z.; Zhao, L. Isolation and Identification of Chemical Constituents from Zhideke Granules by Ultra-Performance Liquid Chromatography Coupled with Mass Spectrometry. J. Anal. Methods Chem. 2020, 2020, 1-16. [CrossRef] [PubMed]

48. Lu, Y.; Foo, L.Y. Polyphenolics of Salvia-A review. Phytochemistry 2002, 59, 117-140. [CrossRef]

49. Zhang, W.-X.; Feng, M.; Miao, Y.-L.; Li, Y.-Y.; Tong, L.-G.; He, P.; Ni, Y. Analysis of chemical components of Huanbei Zhike Prescription based on UPLC-Q-TOF-MS/MS technology. China J. Chin. Mater. Med. 2019, 44, 3022-3034.

50. Girish, T.; Kumar, K.A.; Rao, U.P. C- Glycosylated flavonoids from black gram husk: Protection against DNA and erythrocytes from oxidative damage and their cytotoxic effect on HeLa cells. Toxicol. Rep. 2016, 3, 652-663. [CrossRef] [PubMed]

51. Yin, Z.; Zhang, W.; Feng, F.; Zhang, Y.; Kang, W. $\alpha$-Glucosidase inhibitors isolated from medicinal plants. Food Sci. Hum. Wellness 2014, 3, 136-174. [CrossRef]

52. Inthongkaew, P.; Chatsumpun, N.; Supasuteekul, C.; Kitisripanya, T.; Putalun, W.; Likhitwitayawuid, K.; Sritularak, B. $\alpha-$ Glucosidase and pancreatic lipase inhibitory activities and glucose uptake stimulatory effect of phenolic compounds from Dendrobium formosum. Rev. Bras. Farm. 2017, 27, 480-487. [CrossRef]

53. López-Martínez, L.X.; Aguilar Cisneros, L.M.; Dublán-García, O. Actividad antioxidante e inhibidora de $\alpha$-glucosidasa y $\alpha$-amilasa de tres variedades de cebolla (Allium cepa L.). Nova Sci. 2014, 6, 234-347. [CrossRef]

54. Hogan, S.; Zhang, L.; Li, J.; Sun, S.; Canning, C.; Zhou, K. Antioxidant rich grape pomace extract suppresses postprandial hyperglycemia in diabetic mice by specifically inhibiting alpha-glucosidase. Nutr. Metab. 2010, 7, 71. [CrossRef] [PubMed]

55. Pereira, D.F.; Cazarolli, L.H.; Lavado, C.; Mengatto, V.; Figueiredo, M.S.R.B.; Guedes, A.; Pizzolatti, M.G.; Silva, F.R.M.B. Effects of flavonoids on $\alpha$-glucosidase activity: Potential targets for glucose homeostasis. Nutrition 2011, 27, 1161-1167. [CrossRef] [PubMed] 
56. Lin, L.; Dong, Y.; Zhao, H.; Wen, L.; Yang, B.; Zhao, M. Comparative evaluation of rosmarinic acid, methyl rosmarinate and pedalitin isolated from Rabdosia serra (MAXIM.) HARA as inhibitors of tyrosinase and $\alpha$-glucosidase. Food Chem. 2011, 129, 884-889. [CrossRef]

57. Meng, Y.; Su, A.; Yuan, S.; Zhao, H.; Tan, S.; Hu, C.Y.; Deng, H.; Guo, Y. Evaluation of Total Flavonoids, Myricetin, and Quercetin from Hovenia dulcis Thunb. As Inhibitors of $\alpha$-Amylase and $\alpha$-Glucosidase. Plant Foods Hum. Nutr. 2016, 71, 444-449. [CrossRef]

58. Şöhretoğlu, D.; Sari, S.; Barut, B.; Özel, A. Discovery of potent $\alpha$-glucosidase inhibitor flavonols: Insights into mechanism of action through inhibition kinetics and docking simulations. Bioorg. Chem. 2018, 79, 257-264. [CrossRef]

59. Liu, Y.; Zhan, L.; Xu, C.; Jiang, H.; Zhu, C.; Sun, L.; Sun, C.; Li, X. $\alpha$-Glucosidase inhibitors from Chinese bayberry (Morella rubra Sieb. et Zucc.) fruit: Molecular docking and interaction mechanism of flavonols with different B-ring hydroxylations. RSC Adv. 2020, 10, 29347-29361. [CrossRef]

60. Xngo, Y.L.; Chua, Y.L.N.A.L.S.; Ngo, Y.L. Anti-diabetic Activity of Rosmarinic Acid Rich Fractions from Orthosiphon stamineus. Curr. Enzym. Inhib. 2018, 14, 97-103. [CrossRef]

61. Kotowaroo, M.I.; Mahomoodally, M.F.; Gurib-Fakim, A.; Subratty, A.H. Screening of traditional antidiabetic medicinal plants of mauritius for possible $\alpha$-amylase inhibitory effectsin vitro. Phytother. Res. 2006, 20, 228-231. [CrossRef] [PubMed]

62. Grussu, D.; Stewart, D.; McDougall, G.J. Berry Polyphenols Inhibit $\alpha$-Amylase In Vitro: Identifying Active Components in Rowanberry and Raspberry. J. Agric. Food Chem. 2011, 59, 2324-2331. [CrossRef]

63. Subramaniam, S.; Selvaduray, K.R.; Radhakrishnan, A.K. Bioactive Compounds: Natural Defense against Cancer? Biomolecules 2019, 9, 758. [CrossRef] [PubMed]

64. Karasawa, M.M.G.; Mohan, C. Fruits as Prospective Reserves of bioactive Compounds: A Review. Nat. Prod. Bioprospect. 2018, 8, 335-346. [CrossRef]

65. Al-Attabi, Z.H.; Al Hasani, S.; Waly, M.; Rahman, M.S.; Tamimi, Y. Antioxidant and Antitumor Properties of Wild Blueberry (Sideroxylon mascatense): Effects of Drying Methods. Int. J. Nutr. Pharmacol. Neurol. Dis. 2021, 11, 71. [CrossRef]

66. Vahabi, L.; Monajemi, R.; Hosseini, S.A. The Cytotoxic Effect of Methanolic Extract of Pyracanthacoccinea M. Roemer Fruit on Hela Cell Line, Antioxidant Capacities and Total Phenol Contents of Methanolic and Aquatic Extract of this Fruit. Biomed. Pharmacol. J. 2015, 8, 99-103. [CrossRef]

67. Razavi, S.M.; Ghasemiyan, A.; Salehi, S.; Zahri, F. Screening of biological activity of Zosima absinthifolia fruits extracts. EurAsian J. Biosci. 2009, 25-28. [CrossRef]

68. Nie, J.; Li, R.; Wang, Y.; Tan, J.; Tang, S.; Jiang, Z.-T. Antioxidant activity evaluation of rosemary ethanol extract and their cellular antioxidant activity toward HeLa cells. J. Food Biochem. 2019, 43, e12851. [CrossRef] [PubMed]

69. Yang, J.; Liu, R.H. Synergistic Effect of Apple Extracts and Quercetin 3- $\beta$-d-Glucoside Combination on Antiproliferative Activity in MCF-7 Human Breast Cancer Cells In Vitro. J. Agric. Food Chem. 2009, 57, 8581-8586. [CrossRef]

70. Lyashenko, S.; Fabrikov, D.; González-Fernández, M.J.; Gómez-Mercado, F.; Ruiz, R.L.; Fedorov, A.; de Bélair, G.; Urrestarazu, M.; Rodríguez-García, I.; Álvarez-Corral, M.; et al. Phenolic composition and in vitro antiproliferative activity of Borago spp. seed extracts on HT-29 cancer cells. Food Biosci. 2021, 42, 101043. [CrossRef]

71. Yi, W.; Fischer, J.; Krewer, G.; Akoh, C.C. Phenolic Compounds from Blueberries Can Inhibit Colon Cancer Cell Proliferation and Induce Apoptosis. J. Agric. Food Chem. 2005, 53, 7320-7329. [CrossRef] [PubMed] 